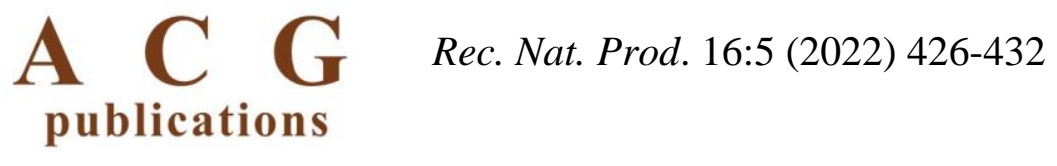

\title{
A New Iridoid Glucoside from the Stems of Myoporum bontioides (Sieb.et Zucc.) A. Gray
}

\section{Tran Thi Minh $\oplus^{*}$,Nguyen Thi Viet Thanh $\odot$ and Vu Dinh Hoang}

\author{
${ }^{1}$ School of Chemical Engineering, Hanoi University of Science and Technology, Hanoi 112456, Vietnam
}

(Received August 30, 2021; Revised October 25, 2021; Accepted October 29, 2021)

\begin{abstract}
A phytochemical investigation of the stems of Myoporum bontioides (Sieb. et Zucc.) A. Gray, a semimangrove plant distributed along coastlines of north-eastern Vietnam and some Asian countries led to the isolation of a new iridoid glucoside (1), named myobontioside E, together with fourteen known compounds (215). Their structures were elucidated by means of HR ESI-MS, 1D and 2D NMR spectroscopy as well as comparison with the data reported in the literature. The cytotoxic effects on 8505C, MKN7, HT29, and T24 cell lines were assessed using SRB assay. Only iridoid $\mathbf{2}$ exhibited weak cytotoxicity against all tested cell lines with $\mathrm{IC}_{50}$ values ranging from 60.19 to $69.14 \mu \mathrm{M}$.
\end{abstract}

Keywords: Myoporum bontioides; Myoporaceae; iridoid glucoside; dammarane saponin; cytotoxicity. @ 2021 ACG Publications. All rights reserved.

\section{Introduction}

Myoporum, a genus of the family Myoporaceae, comprises approximately 32 species that occur throughout the Pacific region and Indian Ocean on Mauritius and Rodriguez islands [1]. Myoporum bontioides (Sieb. et Zucc.) A. Gray, a small shrubby semi-mangrove tree belonging to the family Myoporaceae, is mainly distributed along coastlines of north-eastern Vietnam, south China, Taiwan and Japan, and it has long been used to treat dermatitis, pulpitis and sciatica [2-3]. Previous chemical investigations mainly focused on the leaves of $M$. bontioides and revealed the presence of major constituents including sesquiterpenes [4-5], iridoids [6], flavonoids and phenylethanoids [7-10]. Some of these compounds have activities against bacteria [5, 10], plant pathogenic fungi $[8,11]$, and cancer [7]. In a previous paper, we reported the isolation and structural characterization of three flavonoids, along with the chemical composition of essential oil from the leaves of $M$. bontioides [12]. As a continuation of our investigation on this plant, we have isolated and structurally elucidated a new iridoid glucoside (1), together with fourteen known compounds including iridoids and iridoid glucosides (2-7), $O$-coumaric acid glucosides (8-9), aliphatic alcohol glycosides (10-11), a lignan glucoside (12), and dammarane saponins (13-15) from the $n$-BuOH soluble fraction of the methanol extract of $M$. bontioides stems. The cytotoxicity of iridoids and iridoid glucosides (1-7) against four human cancer cell lines 8505C, MKN7, HT29, and T24 was also reported.

\footnotetext{
* Corresponding author: E-Mail: minh.tranthi@ hust.edu.vn; Phone:0084-988557877 Fax: 0084-24-38690070
} 


\section{Materials and Methods}

\subsection{General Experimental Procedures}

Optical rotations were measured with a JASCO P-2000 polarimeter (Hachioji, Japan) using $\mathrm{MeOH}$ as the solvent. NMR experiments were conducted on a Bruker Avance $500 \mathrm{MHz}$ spectrometer with chemical shifts given in ppm $(\delta)$. HR-ESI-MS were obtained on a X500 QTOF mass spectrometer system (MA, USA). Column chromatography (CC) was performed using silica gel 60 (0.04-0.063 mm, Merck), C18 reversed-phase (RP) silica gel (150 $\mu \mathrm{m}$, YMC), Diaion HP 20 (Mitsubishi chemical Co.), and Sephadex LH-20 (25-100 $\mu \mathrm{m}$, Sigma-Aldrich). Thin-layer chromatography was performed using precoated silica gel 60 F254 and RP-18 F254S plates $(0.25$ $\mathrm{mm}$, Merck), and compounds were detected by UV fluorescence at $254 \mathrm{~nm}$ or spraying with $1 \%$ vanillin- $\mathrm{H}_{2} \mathrm{SO}_{4}$ in $\mathrm{MeOH}$, followed by heating at $100{ }^{\circ} \mathrm{C}$ for $1-2 \mathrm{~min}$.

\subsection{Plant Material}

The stems of Myoporum bontioides (Sieb. et Zucc.) A. Gray were collected in May, 2020 from coastal areas of Thai Binh province in northern Vietnam. The plant material was identified by Prof. Tran Huy Thai, Institute of Ecology and Biological Resources, Vietnam Academy of Science and Technology (VAST). A voucher sample (HUST.N05) was deposited at the Department of Organic Chemistry, School of Chemical Engineering, Hanoi University of Science and Technology (HUST), Vietnam.

\subsection{Extraction and Isolation}

The air-dried stems $(2.0 \mathrm{~kg})$ of $M$. bontioides were extracted three times with $\mathrm{MeOH}(3 \times 7 \mathrm{~L})$ at $45{ }^{\circ} \mathrm{C}$ for $1 \mathrm{~h}$ under sonication. The three extracts were combined and evaporated under reduced pressure to obtain a residue ( $335 \mathrm{~g}$ ). This crude extract was suspended in $\mathrm{H}_{2} \mathrm{O}(2 \mathrm{~L})$ and successively partitioned with $n$-hexane, EtOAc, and $n$-BuOH to afford $n$-hexane $(27 \mathrm{~g})$, EtOAc $(46 \mathrm{~g})$, and $n$ $\mathrm{BuOH}(120 \mathrm{~g})$ residues, after removal of the solvents.

The $n$-BuOH soluble fraction $(120 \mathrm{~g})$ was subjected to Diaion HP20 CC, eluting with water and increasing concentration of $\mathrm{MeOH}$ in water $(20,40,60,80,100 \%$, v/v) to afford five fractions Fr.1Fr.5. Fraction Fr.1 (20\% MeOH, 12.8 g) was chromatographed on an $\mathrm{RP}^{-\mathrm{C}_{18}}$ silica gel column, eluting with $\mathrm{MeOH} / \mathrm{H}_{2} \mathrm{O}(1: 3,1: 1$, v/v) to give four subfractions Fr.1.1-Fr.1.4. Subfraction Fr.1.2 $(0.4 \mathrm{~g})$ was purified by silica gel $\mathrm{CC}$ with $\mathrm{CH}_{2} \mathrm{Cl}_{2} / \mathrm{MeOH}(9: 1$, v/v) and then by Sephadex LH-20 $\mathrm{CC}$ with $\mathrm{MeOH}$ to obtain compound $4(6.8 \mathrm{mg})$. Fr.1.3 (4.8 g) was fractionated on a silica gel CC, eluting with a $\mathrm{CH}_{2} \mathrm{Cl}_{2} / \mathrm{MeOH}$ (10:1 to $1: 1$, v/v) gradient to afford eight subfractions Fr.1.3.1Fr.1.3.8. Subfraction Fr.1.3.1 was purified by Sephadex LH-20 CC with MeOH and then by silica gel $\mathrm{CC}$ with $\mathrm{CH}_{2} \mathrm{Cl}_{2} /$ acetone $(5: 1, \mathrm{v} / \mathrm{v})$ to give compounds $2(5.1 \mathrm{mg})$ and $3(25.4 \mathrm{mg})$. Fr.1.3.6, Fr.1.3.7 and Fr.1.3.8 were purified by RP-C ${ }_{18}$ silica gel CC, eluting with $\mathrm{MeOH} / \mathrm{H}_{2} \mathrm{O}(1: 2, \mathrm{v} / \mathrm{v})$ to yield compounds $5(32.8 \mathrm{mg}), 7(17 \mathrm{mg})$ and $8(24.2 \mathrm{mg})$, respectively. Compound $\mathbf{6}(25 \mathrm{mg})$ was isolated from Fr.1.4 (1.6 g) by RP-C18 CC, eluting with $\mathrm{MeOH} / \mathrm{H}_{2} \mathrm{O}(1: 3$, v/v). Fraction Fr.2 (40\% $\mathrm{MeOH}, 8.3 \mathrm{~g})$ was fractionated on an $\mathrm{RP}_{-} \mathrm{C}_{18}$ silica gel CC, eluting with $\mathrm{MeOH} / \mathrm{H}_{2} \mathrm{O}(3: 1,1: 1$, v/v) to provide three subfractions Fr.2.1 -Fr.2.3. Subfraction Fr.2.1 (0.37 g) was purified by Sephadex LH$20 \mathrm{CC}$ with $\mathrm{MeOH}$ to give compound 9 (72 mg). Fr.2.2 (1.1 g) was purified by Sephadex LH-20 CC with $\mathrm{MeOH}$ and then by $\mathrm{RP}_{-} \mathrm{C}_{18}$ silica gel $\mathrm{CC}$ with $\mathrm{MeOH} / \mathrm{H}_{2} \mathrm{O}(1: 1, \mathrm{v} / \mathrm{v})$ to yield compound 11 (21 $\mathrm{mg})$. Compound $10(40.5 \mathrm{mg})$ was obtained from the $F r .2 .3$ by $\mathrm{RP}^{-C_{18}}$ silica gel CC, eluting with acetone $/ \mathrm{H}_{2} \mathrm{O}(2: 1, \mathrm{v} / \mathrm{v})$. Fraction $F r .3(60 \% \mathrm{MeOH}, 7.4 \mathrm{~g})$ was subjected to silica gel CC, eluting with a $\mathrm{CH}_{2} \mathrm{Cl}_{2} / \mathrm{MeOH}(10: 1$ to $1: 1$, v/v) gradient to afford twelve subfractions Fr.3.1-Fr.3.12. Subfractions Fr.3.5 and Fr.3.7 were purified by $\mathrm{RP}-\mathrm{C}_{18}$ silica gel CC, eluting with acetone $/ \mathrm{H}_{2} \mathrm{O}(1: 2, \mathrm{v} / \mathrm{v})$ to yield compounds $14(27 \mathrm{mg})$ and $12(17 \mathrm{mg})$. Fr.3.10 was subjected to Sephadex LH-20 CC with MeOH, followed by RP-C 18 silica gel CC with $\mathrm{MeOH} / \mathrm{H}_{2} \mathrm{O}(1: 2, \mathrm{v} / \mathrm{v})$ to afford compounds $\mathbf{1}(8 \mathrm{mg})$ and $\mathbf{1 3}$ 
A new iridoid glucoside

(29.7 mg). Fr.3.11 was purified by Sephadex LH-20 CC with MeOH and then by RP-C $_{18}$ silica gel CC with $\mathrm{MeOH} / \mathrm{H}_{2} \mathrm{O}(2: 3, \mathrm{v} / \mathrm{v})$ to yield $15(3.5 \mathrm{mg})$.

Myobontioside $E(\mathbf{1})$ : White powder. $[\alpha]_{D}^{25}=-49.3$ (c 0.1, MeOH); HR ESI-MS: $m / z 603.1560$ $[M+\mathrm{HCOOH}-\mathrm{H}]^{-}$(calcd. for $\left.\mathrm{C}_{25} \mathrm{H}_{31} \mathrm{O}_{17}, 603.15667\right) ;{ }^{1} \mathrm{H} \mathrm{NMR}\left(500 \mathrm{MHz}, \mathrm{CD}_{3} \mathrm{OD}\right)$ and ${ }^{13} \mathrm{C} \mathrm{NMR}$ $\left(125 \mathrm{MHz}, \mathrm{CD}_{3} \mathrm{OD}\right)$ data are given in Table 1.

\subsection{Acid hydrolysis and sugar identification}

Compound $1(2.0 \mathrm{mg})$ was refluxed with $2 \mathrm{~N}$ methanolic $\mathrm{HCl}(5 \mathrm{~mL})$ for $2 \mathrm{~h}$. After neutralization with $1 \mathrm{~N}$ sodium carbonate solution, the reaction mixture was extracted with $\mathrm{CHCl}_{3}$ to remove the aglycone. In the aqueous layer, D-glucose was identified by the optical rotation and TLC comparison with an authentic sample $\left[R_{f} 0.17\right.$, EtOAc-MeOH- $\left.\mathrm{H}_{2} \mathrm{O}(4: 1: 0.1, \mathrm{v} / \mathrm{v}),[\alpha]_{D}^{25}+45.7\right]$.

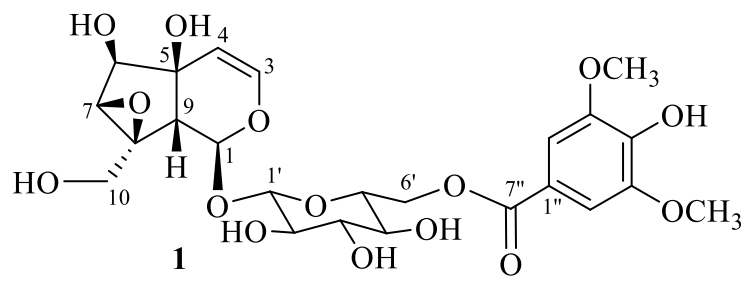<smiles>[R]C1C[C@]2(O)[C@@H](O)[C@H](Cl)[C@]([2H])(O)[C@@]2(C)[C@H](O)O1</smiles>

2: $\mathrm{R}=\mathrm{H}$

3: $\mathrm{R}=\mathrm{OH}$<smiles>CO[C@H]1OC=C[C@H]2[C@@H](O)C[C@H](O)[C@H]12</smiles>

5<smiles>[R]OC(C=C)CCCCC</smiles>

10: $\mathrm{R}=$ Glc $\left(2^{\prime}-1^{\prime \prime}\right)$ Glc

11: $\mathrm{R}=$ Glc $\left(2^{\prime}-1^{\prime \prime}\right)$ Glc (6'-1"') Xyl<smiles>[R]C1[C@H](O)[C@@H](O)[C@]2(O)C=CO[C@H](OC)[C@H]12</smiles>

6: $\mathrm{R}=\mathrm{OCOCH}_{3}$ 7: $\mathrm{R}=\mathrm{OH}$<smiles>COc1cc(C[C@@H]2COC(c3ccc(O)c(OC)c3)[C@H]2COCl)ccc1O</smiles><smiles>O=C(O)C=Cc1ccccc1OC(=O)Cl</smiles>

8<smiles>CO[C@H]1OC=C(C(=O)O)[C@H]2C[C@H](O)[C@@H](C)[C@H]12</smiles>

4<smiles>CC(=O)Oc1ccccc1/C=C/C(=O)O</smiles>

9

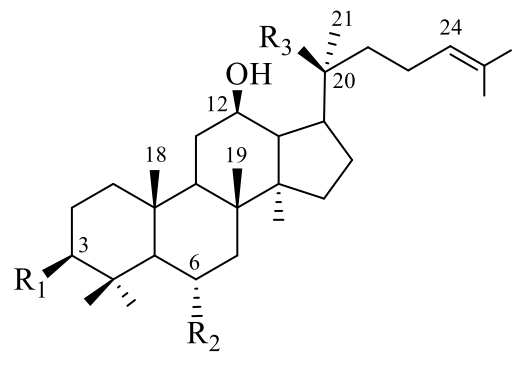

13: $\mathrm{R}_{1}=\mathrm{OH}, \mathrm{R}_{2}=\mathrm{Glc}, \mathrm{R}_{3}=\mathrm{Glc}$

14: $\mathrm{R}_{1}=\mathrm{OH}, \mathrm{R}_{2}=$ Glc (2'-1") Xyl, $\mathrm{R}_{3}=$ Glc

15: $R_{1}=\operatorname{Glc}\left(2^{\prime}-1 "\right) G l c, R_{2}=H, R_{3}=$ Glc $\left(6^{\prime \prime \prime}-1 " '\right)$ Glc

Figure 1. Chemical structures of compounds 1-15

\subsection{Cytotoxic Assay}

The sulforhodamine B (SRB) method [13] was used to evaluate cytotoxic activity of seven iridoids 1-7 against four human cancer cell lines as $8505 \mathrm{C}$ (thyroid carcinoma), MKN7 (gastric carcinoma), HT29 (colorectal adenocarcinoma), and T24 (urinary bladder carcinoma) following the previously described protocol [14]. All tumor cell lines were supplied by Professor J. M. Pezzuto (Long-Island University, US) and Professor Jeanette Maier (Milan University, Italia). Ellipticine was used as a positive control. 


\section{Results and Discussion}

\subsection{Structure Elucidation}

The $n-\mathrm{BuOH}$ soluble fraction was subjected to multiple chromatographic separations to afford fifteen compounds (1-15, Figure 1).

Myobontioside E (1) was isolated as a white powder. Its molecular formula was determined as $\mathrm{C}_{24} \mathrm{H}_{30} \mathrm{O}_{15}$ by the HR ESI-MS at $\mathrm{m} / z 603.1560$ [M + FA - H] (calcd. 603.15667) and NMR spectroscopic data (Table 1). The ${ }^{1} \mathrm{H}$ NMR spectrum of 1 showed signals of two symmetrical aromatic protons at $\delta_{\mathrm{H}} 7.35(2 \mathrm{H}, s)$, cis-olefinic protons at $\delta_{\mathrm{H}} 6.35$ and 4.92 (both $1 \mathrm{H}, d, J=6.0 \mathrm{~Hz}$ ), an acetal proton at $\delta_{\mathrm{H}} 5.13(1 \mathrm{H}, d, J=9.0 \mathrm{~Hz})$, two oxygenated methylene groups at $\delta_{\mathrm{H}} 4.60(2 \mathrm{H}, m), 4.10$ and 3.54 (both $1 \mathrm{H}, d, J=13.0 \mathrm{~Hz}$ ), an anomeric proton at $\delta_{\mathrm{H}} 4.78(1 \mathrm{H}, d, J=8.0 \mathrm{~Hz}$ ), along with other sugar proton signals at $\delta_{\mathrm{H}} 3.30-3.64$, two symmetrical methoxy groups at $\delta_{\mathrm{H}} 3.92(6 \mathrm{H}, s)$, and one non-deshielded methine proton $\delta_{\mathrm{H}} 2.55(1 \mathrm{H}, d, J=9.0 \mathrm{~Hz})$. The ${ }^{13} \mathrm{C}$ NMR spectrum exhibited signal for a carboxyl carbon at $\delta_{\mathrm{C}} 167.9$, four carbon signals for a symmetrical aromatic ring, a carbon signal for two methoxy groups at $\delta_{\mathrm{C}} 57.0$, nine carbon signals for $\mathrm{C}_{9}$-type iridoid aglycone, and six carbon signals for a glucosyl moiety, which included an anomeric carbon signal at $\delta_{\mathrm{C}} 99.8$. The ${ }^{1} \mathrm{H}$ and ${ }^{13} \mathrm{C}$ NMR signals of 1 (Table S1) were in good agreement with those of myobontioside B, a known iridoid glucoside isolated from the same species of Japan [6], except that the signals of the ferulic acid in myobontioside B replaced by signals of a syringic acid. The syringyl moiety was linked by an ester bond to the hydroxyl group of $\mathrm{C}-6^{\prime}\left(\delta_{\mathrm{C}} 64.4, \delta_{\mathrm{H}} 4.60\right)$, which was confirmed by the HMBC correlation from $\mathrm{H}_{2}-6^{\prime}$ to $\mathrm{C}-7{ }^{\prime \prime}\left(\delta_{\mathrm{C}} 167.9\right)$. Noted that the HMBC spectrum also showed the correlations from two methoxy groups $\left(\delta_{\mathrm{H}} 3.92\right)$ to C-3", $5^{\prime \prime}\left(\delta_{\mathrm{C}} 149.0\right)$, from H-2", $6^{\prime \prime}\left(\delta_{\mathrm{H}} 7.35\right)$ to the carboxyl carbon C-7" $\left(\delta_{\mathrm{C}} 167.9\right)$. In addition, the NOESY spectrum of 1 exhibited correlation between $\delta_{\mathrm{H}} 3.92\left(\mathrm{OCH}_{3}\right)$ and $\delta_{\mathrm{H}} 7.35\left(\mathrm{H}-2^{\prime \prime}, 6 "\right)$, indicating the syringyl moiety. The relative configuration of $\mathbf{1}$ was confirmed according to structure of myobontioside B and based on $J$ values and NOESY spectroscopic analysis. The NOE correlations of H-6 $\left(\delta_{\mathrm{H}} 3.81\right)$ with H-7 $\left(\delta_{\mathrm{H}} 3.45\right)$, and also of H-6 with H-1 $\left(\delta_{\mathrm{H}} 5.13\right)$ indicated that H-1, H-6 and H-7 were on the same side and designated as $\alpha$-oriented (Figure 2). The small coupling constant $\left(J_{6,7}=1.0 \mathrm{~Hz}\right)$ between H-6 and H-7 also supported this conformation. The large coupling constant $\left(J_{1,9}=9.0 \mathrm{~Hz}\right)$ between $\mathrm{H}-1$ and $\mathrm{H}-9$ suggested that they were present in transdiaxial relationship and positioning $\mathrm{H}-9$ in $\beta$-orientation $[6,15]$. Based on this evidence, the compound 1 was determined to be a new compound as macfadyenoside- 6 '-syringic acid ester.

Table 1. ${ }^{1} \mathrm{H}$ (at $500 \mathrm{MHz}$ ) and ${ }^{13} \mathrm{C}$ (at $125 \mathrm{MHz}$ ) NMR data for compound $\mathbf{1}$ in $\mathrm{CD}_{3} \mathrm{OD}$

\begin{tabular}{llllll}
\hline Position & $\delta_{C}$ & $\delta_{H}, J$ in $\mathrm{Hz}$ & Position & $\delta_{C}$ & $\delta_{H}, J$ in Hz \\
\hline 1 & $95.5(\mathrm{CH})$ & $5.13(1 \mathrm{H}, d, J=9.0)$ & Glc-1' & $99.8(\mathrm{CH})$ & $4.78(1 \mathrm{H}, d, J=8.0)$ \\
2 & - & - & $2^{\prime}$ & $74.7(\mathrm{CH})$ & $3.30(1 \mathrm{H}, d d, J=8.0,9.0)$ \\
3 & $142.6(\mathrm{CH})$ & $6.35(1 \mathrm{H}, d, J=6.0)$ & $3^{\prime}$ & $77.5(\mathrm{CH})$ & $3.45(1 \mathrm{H}, m)$ \\
4 & $108.0(\mathrm{CH})$ & $4.92(1 \mathrm{H}, d, J=6.0)$ & $4^{\prime}$ & $71.8(\mathrm{CH})$ & $3.45(1 \mathrm{H}, m)$ \\
5 & $74.4(\mathrm{C})$ & - & $5^{\prime}$ & $76.0(\mathrm{CH})$ & $3.64(1 \mathrm{H}, m)$ \\
6 & $78.7(\mathrm{CH})$ & $3.81(1 \mathrm{H}, d, J=1.0)$ & $6^{\prime}$ & $64.4(\mathrm{CH})$ & $4.60(2 \mathrm{H}, m)$ \\
7 & $63.2(\mathrm{CH})$ & $3.45(1 \mathrm{H}, m)$ & Acyl-1" & $121.3(\mathrm{C})$ & - \\
8 & $66.5(\mathrm{C})$ & - & $2^{\prime \prime}, 6^{\prime \prime}$ & $108.4(\mathrm{CH})$ & $7.35(2 \mathrm{H}, s)$ \\
9 & $50.9(\mathrm{CH})$ & $2.55(1 \mathrm{H}, d, J=9.0)$ & $3^{\prime \prime}, 5^{\prime \prime}$ & $149.0(\mathrm{C})$ & - \\
10 & $61.5\left(\mathrm{CH}_{2}\right)$ & $4.10(1 \mathrm{H}, d, J=13.0)$ & $4^{\prime \prime}$ & $142.6(\mathrm{C})$ & - \\
& & $3.54(1 \mathrm{H}, d, J=13.0)$ & $7^{\prime \prime}$ & $167.9(\mathrm{C})$ & - \\
& & $3^{\prime \prime}, 5^{\prime \prime}-\mathrm{OCH}_{3}$ & $57.0\left(\mathrm{CH}_{3}\right)$ & $3.92(6 \mathrm{H}, s)$ \\
\hline
\end{tabular}

The structures of fourteen isolates (2-15) were identified as myopochlorin (2) [6], 3hydroxymyopochlorin (3) [16], 8-epi-loganic acid (4) [17], ajugol (5) [18], 8-O-acetylharpagide (6) [19], harpagide (7) [20], cis-melilotoside (8) and trans-melilotoside (9) [21-22], octane-1-en-3-ol-3-O$\beta$-D-glucopyranosyl $(1 \rightarrow 2)-\beta$-D-glucopyranoside (10) [23], ebracteatoside B (11) [24], lariciresinol-9- 
$O$ - $\beta$-D-glucopyranoside (12) [25], ginsenoside $\operatorname{Rg} 1$ (13) [26], notoginsenoside-R1 (14) [27], and ginsenoside $\mathrm{Rb} 1$ (15) [28] by detailed analysis of their 1D- and 2D-NMR spectroscopic data in comparison with those reported in the literature. This is the first report on the isolation of aliphatic alcohol glycosides (10-11) and dammarane saponins (13-15) from this genus [3].
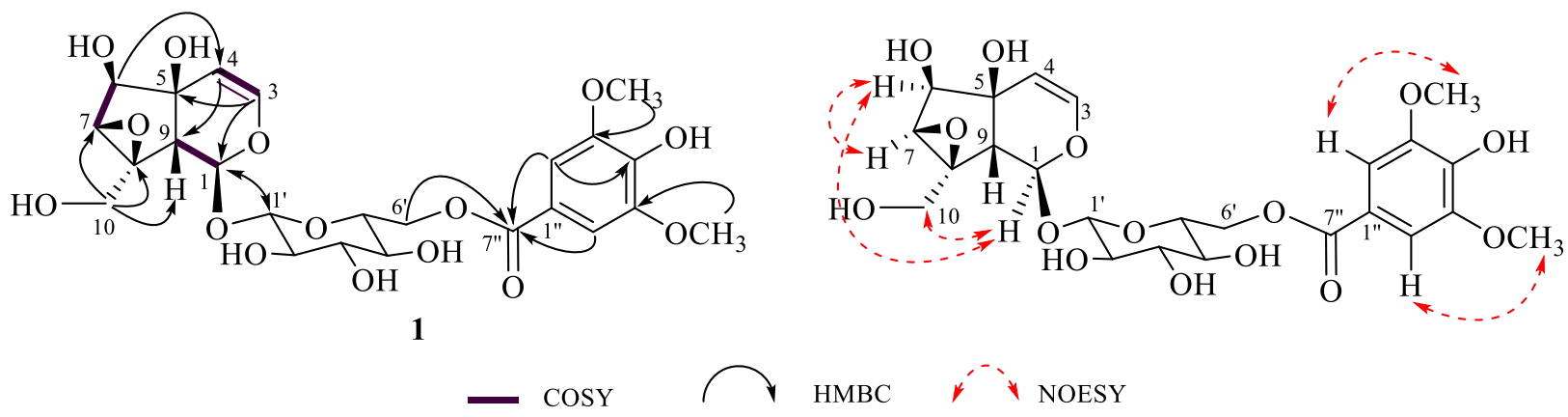

Figure 2. ${ }^{1} \mathrm{H}-{ }^{1} \mathrm{H}$ COSY and the selected HMBC, NOESY correlations of compound 1

\subsection{Cytotoxicity Activity}

Iridoids and iridoid glucosides 1-7 were evaluated in vitro for their cytotoxicity against the 8505C, MKN7, HT29, and T24 human cancer cell lines using SRB method with ellipticine as the positive control [13-14]. As the obtained results, only myopochlorin (2) exhibited weak cytotoxicity against all the tested cancer cell lines with the $\mathrm{IC}_{50}$ values of $60.19 \pm 1.75,64.25 \pm 1.41,67.65 \pm 1.32$, and $69.14 \pm$ $1.37 \mu \mathrm{M}$, respectively. The other compounds were inactive in this test $\left(\mathrm{IC}_{50}>100 \mu \mathrm{M}\right)$.

\section{Acknowledgments}

This research is funded by Vietnam National Foundation for Science and Technology Development (NAFOSTED) under grant number 104.01-2018.36.

\section{Supporting Information}

Supporting information accompanies this paper on http://www.acgpubs.org/journal/records-ofnatural-products

\section{ORCID}

Tran Thi Minh: 0000-0003-0784-4217

Nguyen Thi Viet Thanh: 0000-0001-8857-0224

Vu Dinh Hoang: 0000-0002-2112-6732

\section{References}

[1] G. S. Richmond and E. L. Ghisalberti (1995). Cultural, food, medicinal uses and potential applications of Myoporum species (Myoporaceae), Econ. Botan. 49, 276-285.

[2] H. H. Pham (1999). An Illustrated Flora of Vietnam. Hanoi Young Publishing House (in Vietnamese), Hanoi, Vietnam. 3, p. 11.

[3] A. Musa (2021). Phytochemistry, pharmacological potency, and potential toxicity of Myoporum spp. Rec. Nat. Prod. 15, 148-168.

[4] Q. Wang, C. Ma and J. Zhai (2000). Furanoeudesmane-B, a new eudesmane sesquiterpenoid from Myoporum bontioides, Acta Cryst. C56, e569. 
[5] L. M. Dong, L. L. Huang, H. Dai, Q. L. Xu, J. K. Ouyang, X. C. Jia, W. X. Gu and J. W. Tan (2018). Anti-MRSA sesquiterpenes from the semi-mangrove plant Myoporum bontioides A. Gray, Mar. Drugs 16, 438-445.

[6] M. Kanemoto, K. Matsunami, H. Otsuka, T. Shinzato, C. Ishigaki and Y. Takeda (2008). Chlorinecontaining iridoid and iridoid glucoside and other glucosides from leaves of Myoporum bontioides, Phytochemistry 69, 2517-2522.

[7] J. R. Weng, L. Y. Bai, W. Y. Lin, C. F. Chiu, Y. C. Chen, S. W. Chao and C. H. Feng (2017). A flavone constituent from Myoporum bontioides induces M-Phase cell cycle arrest of MCF-7 breast cancer cells, Molecules 22, 472-484.

[8] L. L. Huang, J. W. Li, C. L. Ni, W. X. Gu and C. Y. Li (2011). Isolation, crystal structure and inhibitory activity against Magnaporthe Grisea of $(2 R, 3 R)-3,5,7$-trihydroxyflavanone 3-acetate from Myoporum Bontioides A. Gray, Chin. J. Struct. Chem. 30, 1298-1304.

[9] T. Iwashina and G. Kokubugata (2010). Flavonoids in the leaves and flowers of Myoporum bontioides native to northernmost region in the Myoporaceae, Bull. Natl. Mus. Nat. Sci. Ser. B. 36, 117-125.

[10] H. Ye, H. Dai, L. Wu, Y. Guo and W. Gu (2014). Chemical constituents from leaves of Myoporum bontioides and their bacteriostatic activities, J. Trop. Subtrop. Bot. 22, 307-313.

[11] D. Yecheng, Y. Zhen, Y. Yanzhen and B. Xiulian (2008). Inhibitory activity against plant pathogenic fungi of extracts from Myoporum bontioides A. Gray and identification of active ingredients, Pest Manag. Sci. 64, 203-207.

[12] T. T. Minh, T. T. Ngoan, N. T. M. Thuong, H. K. Toan, N. X. Truong, T. T. Huong, G. T. P. Ly, D. T. T. Ai, N. D. Khanh (2020). Chemical compositions and bioefficacy against Spodoptera litura of essential oil and ethyl acetate fraction from Myoporum bontioides leaves, Vietnam J. Chem. 58, 57-62.

[13] P. Skehan, R. Storeng, D. Scudiero, A. Monks, J. McMahon, D. Vistica, J. T. Warren, H. Bokesch, S. Kenney and M. R. Boyd (1990). New colorimetric cytotoxic assay for anticancer-drug screening, $J$. Natl. Cancer Inst. 82, 1107-1112.

[14] T. T. Minh, N. H. Thu, H. K. Toan, T. T. Quang, N. T. V. Thanh, T. T. Huong and T. V. Sung (2022). Three new phenolic sulfates from Acrostichum aureum collected from coastal area of Thai Binh province, Vietnam and their cytotoxic activity, Rec. Nat. Prod. 16, 66-73.

[15] E. Davini, C. Iavarone and C. Trogolo (1983). Effect of an 8-hydroxymethyl substituent on the basecatalyzed ring opening of 7,8-epoxyiridoid glucosides, J. Org. Chem. 48, 2854-2857.

[16] C. Lémus, R. Grougnet, E. N. Ellong, W. Tian, M. L. Bornet, S. Adenet, K. Rochefort, S. Michel and H. Dufat (2015). Phytochemical study of Capraria biflora L. Aerial parts (Scrophulariaceae) from Martinique island (French West Indies), Phytochem. Lett. 13, 194-199.

[17] Z. Dogan, K. Ishiuchi, T. Makino and I. Saracoglu (2019). New acylated iridoid glucosides from Scutellaria glaphyrostachys Rech.f. and chemotaxonomic importance for the genus Scutellaria, Phytochem. Lett. 32, 157-161.

[18] S. Damtoft, S. R. Jensen and B. J. Nielsen (1981). ${ }^{13} \mathrm{C}$ and ${ }^{1} \mathrm{H}$ NMR spectroscopy as a tool in the configurational analysis of iridoid glucosides, Phytochemistry, 20, 2717-2732.

[19] Z. Min, M. Mizuo, S. Wang, M. Iinuma and T. Tanaka (1990). Two new neo-clerodane diterpenes in Ajuga decumbens, Chem. Pharm. Bull. 38, 3167-3168.

[20] Y. J. Yu, J. C. Do, K. Y. Jung, S. Y. Kwon and K. H. Son (1998). Studies on the constituents of the Herbs of Ajuga multiflora, Kor. J. Pharmacogn. 29, 75-78.

[21] J. Monton and F. Van der Kooy (2014). Identification of cis- and trans-melilotoside within an Artemisia annua tea infusion, Eur. J. Med. Plants 4, 52-63.

[22] P. M. Giang, V. M. Trang, D. T. V. Huong, S. Kawakami and H. Otsuka (2019). Thymol derivatives from Eupatorium fortunei, Rec. Nat. Prod. 13, 434-439.

[23] N. Li, X. Li, B. L. Hou and D. L. Meng (2008). New disaccharoside from Camptosorus sibiricus Rupr. Nat. Prod. Res. 22, 1379-1383.

[24] T. Kanchanapoom, R. Kasai, C. Picheansoonthon and K. Yamasaki (2001). Megastigmane, aliphatic alcohol and benzoxazinoid glycosides from Acanthus ebracteatus, Phytochemistry 58, 811-817.

[25] H. K. Cho, W. S. Suh, K. H. Kim, S. Y. Kim and K. R. Lee (2014). Phytochemical constituents of Salsola komarovii and their effects on NGF induction, Nat. Prod. Sci. 20, 95-101.

[26] D. S. Kim, Y. J. Chang, U. Zedk, P. Zhao, Y. Q. Liu and C. R. Yang (1995). Dammarane saponins from Panax ginseng, Phytochemistry 40, 1493-1497. 


\section{A new iridoid glucoside}

[27] J. Zhou, M. Wu, S. Taniyasu, H. Besso, O. Tanaka, Y. Saruwatari, and T. Fuwa (1981). Dammarane saponins of Sanchi Ginseng, roots of Panax notoginseng (Burk.) F. H. Chen (Araliaceae): Structures of new saponins Notoginsenoides-R1 and $-\mathrm{R} 2$, and identification of Ginsenoides-Rg $\mathrm{g}_{2}$ and $-\mathrm{Rh}_{1}$, Chem. Pharm. Bull. 29, 2844-2850.

[28] J. G. Cho, M. K. Lee, J. W. Lee, H. J. Park, D. Y. Lee, Y. H. Lee, D. C. Yangand N. I. Baek (2010). Physicochemical characterization and NMR assignments of ginsenosides Rb1, Rb2, Rc, and Rd isolated from Panax ginseng, J. Ginseng Res. 34, 113-121.

$$
\underset{\substack{\text { publications } \\ \text { (C) } 2021 \text { ACG Publications }}}{\text { C }}
$$

